\title{
THE DIGITAL ACCOUNTING ENTREPRENEURSHIP COMPETENCY FOR SUSTAINABLE PERFORMANCE OF THE RURAL MICRO, SMALL AND MEDIUM ENTERPRISES (MSMES): AN EMPIRICAL REVIEW
}

\author{
Farhana Hasbolah \\ Faculty of Business and Accountancy \\ Universiti Selangor, Shah Alam, Malaysia \\ E-mail: farhana.hasbolah@unisel.edu.my \\ Mohamad Hafiz Rosli \\ Faculty of Accountancy \\ Universiti Teknologi MARA (UiTM) \\ Cawangan Johor, Kampus Segamat, Johor, Malaysia \\ Hanissah Hamzah \\ Faculty of Business and Accountancy \\ Universiti Selangor, Shah Alam, Malaysia \\ Siti Aisyah Omar \\ Faculty of Business and Accountancy \\ Universiti Selangor, Shah Alam, Malaysia \\ Abul Bashar Bhuiyan \\ Faculty of Business and Accountancy \\ Universiti Selangor, Shah Alam, Malaysia
}

\begin{abstract}
A year has passed since the Covid-19 pandemic hit the world and no one could have imagined that it would leave such a massive impact on the world economic landscape. The most affected groups are the Rural Micro, Small, and Medium Enterprises (MSMEs) and micro-entrepreneurs. With the implementation of the Movement Control Order (MCO), the business owners are in dilemma in the way to sustain and maintain their businesses. They need to scrutinize the ability of their businesses to continue operations amid the Covid-19 pandemic. Besides, these business owners were forced to explore new strategies to interact with customers and to simplify transaction processes. A new shift or new normal of the spending habits are formed where individuals are more interested to perform online shopping, and this creates an ideal market environment for business owners to accelerate, test, and launch new experience-driven mobile applications and websites across all their digital platforms. Hence, this study is an empirical attempt to formulate the digital accounting competency model for rural MSMEs. The available online empirical recourses by the name of digital accounting entrepreneurship and sustainable performance of the rural MSMEs in different online database sources such as Google Scholars, Springer Link, Wiley, Science Direct, JSTOR, Emerald full text, Scopus, and EBSCO HOST were
\end{abstract}


used for the review. The review findings hitherto show that digital accounting entrepreneurship has a significant role in ensuring the sustainable performance of the rural MSMEs, especially for entrepreneurial competency, marketing capability, knowledge sharing, financial resources, technology usage, drive change and engagement, and individual competency is considered the most influencing factors toward sustainable performance among the rural MSMEs in the world. This finding, therefore, warrants a more in-depth analysis to develop a digital accounting entrepreneurship competency model.

Keywords: Accounting Entrepreneurship, Competency Model, Digital Entrepreneurship, Sustainable Performance, MSME.

\section{INTRODUCTION}

A year has passed since the Covid-19 pandemic hit the world and no one could have imagined that it would leave such a massive impact on the world economic landscape. The most affected groups are the Rural Micro, Small, and Medium Enterprises (MSMEs) and micro-entrepreneurs. With the implementation of the Movement Control Order (MCO), the business owners are in dilemma in the way to sustain and maintain their businesses. The Covid-19 pandemic has two different impacts on entrepreneurs and business owners where some have recorded sales booming and some have had to swallow bitterness when sales plummeted. The announcement of MCO made in a short period at that time has left them shocked and most unprepared when their business cannot operate as usual, in which have to run under strict Standard Operating Procedures (SOP) and ended up incurred additional costs. Furthermore, the absence of customers is the biggest factor most companies and business owners decide to close their business premises.

During the MCO period, the business owners ensure that their businesses can be maintained and sustain even if business operations are disrupted. With regards to the principle of accounting, it is a must for business owners to make an assessment and report on financial position as if the business will continue forever. They need to scrutinize the ability of their businesses to continue operations amid the Covid-19 pandemic. Besides, these business owners were forced to explore new strategies to interact with customers and to simplify transaction processes (Dwivedi, Ismagilova, \& Hughes, et al., 2020). A new shift or new normal of the spending habits are formed where individuals are more interested to perform online shopping, and this creates an ideal market environment for business owners to accelerate, test, and launch new experience-driven mobile applications and websites across all their digital platforms.

\section{Digital Entrepreneurship}

\section{LITERATURE REVIEW}

Digital entrepreneurship is a term that describes how entrepreneurship will evolve as business and society continue to be transformed by digital technology. According to European Commission (2015), digital entrepreneurship can be defined as a phenomenon associated with the generation of value through the creation and expansion of new ventures and transformation of the existing businesses with the identification of novel digital technologies and novel usage of such technologies. In other words, digital entrepreneurship is a traditional business environment that is digitalized based on the use of digital media and technology (Nambisan, 2017). According to Le Dinh, Vu, and Ayayi (2018), digital entrepreneurship is an expansion of traditional business efforts with the latest technologies to create digital businesses. It is a medium of online 
business transactions using innovative technology infrastructure facilities (Musbri, 2011), to transform the entrepreneurial activities to be able to bring their business to national and world markets.

Lately, many entrepreneurs have developed market opportunities by using online applications such as Facebook, Instagram, Twitter, WhatsApp, Telegram, YouTube, and E-mail to expand and widen their businesses. The social media platform has made a huge impact for many entrepreneurs to take the opportunities to advertise their products and services (Shabbir, Ghazi \& Mehmood, 2016) and thus, generate huge income every month. The application of social media platforms creates entrepreneurial opportunities such as new ways of finding customers, new ways of generating revenue and reducing cost, new opportunities to collaborate with partners, and new ways of designing and offering products and services (Park, Sung \& Im, 2017). Internet-oriented entrepreneurs have shown a significant increase in their business growth as mentioned by Mostafa, Wheeler, and Jones, and Coviello (2005) in Faradillah, Samsudin, and Ali (2015). Digital participation is an advancement used to promote business globally (Faradillah, Nur Ajeerah, \& Nor Azlili, 2019; Faradillah, Samsudin, \& Husna, 2019). In a study conducted by Suriantie and Nor Aishah (2017), the use of social media to introduce and promote business products can increase sales revenue and productivity. The social media platforms create additional opportunities for entrepreneurs (Rippa \& Secundo, 2019).

According to Kraus, Kailer, Kallinger, and Palmer (2019) issues related to digital business continue to change from time to time. The latest development of digital technology brings changes to existing business models and new creations, the introduction of new products and services as well as increased efficiency of business processes which ultimately makes businesses more competitive. Jonathan P. Allan (2019) mentioned in his book that digital entrepreneurship encompasses everything new which includes new methods of identifying target customers, new ways of designing and providing goods or services, new methods of revenue generation and cost reduction, new opportunities to collaborate with partners, and new sources of opportunities, risks, and competitive advantages. A digital business plan needs to be developed which focusing on customer demands, that prioritizes the value chain over the supply chain for the business to sustain and remain competitive. The main issue in the value chain is to solve customer problems, satisfy customer needs and add value to customers. The power of social media can trigger a new phenomenon of entrepreneurship.

\section{Micro, Small, and Medium Enterprises (MSMEs)}

Micro, Small, and Medium Enterprises (MSMEs) comprise several key sectors, namely the manufacturing, services, construction, agriculture, mining, and quarrying sectors. MSMEs are divided into three main sizes, namely micro industries, small industries, and medium-sized industries. These three industry sizes are distinguished by their total annual sales turnover and number of employees. MSMEs play an important role in the development of a country's economy and the local community. The existence of these MSMEs have provided and opened up a wide range of employment opportunities, especially for the low-income rural population. Malaysia and several other countries like South Korea, Singapore, Indonesia, and Thailand were the forerunners that took early initiatives in promoting MSMEs, on the awareness of each that the MSMEs sector can provide a positive impact on economic development in the country (Mohd Rosli, 2000). Since it plays a significant role in the country's economy, the Malaysian government focuses on the development of the rural MSME as a key country resource to transform Malaysia's economic policy into a new high-income generating country. MSMEs play 
a vital role in the Malaysian economy and are considered to be the backbone of industrial development in the country (Salleh \& Ndubisi, 2006).

Each county may define MSMEs differently based on criteria developed that meet its needs, expectations, and demands. MSMEs have distinguishable features in terms of product type, organization, capital, location, worker, and production technology (SME Corp, 2020). MSMEs products are mainly divided into two types; consumer products that meet daily needs such as foods, textiles, furniture, and handcraft. The other type of MSMEs products is the replacement parts to support large industries such as a car, cushions, nuts, and others. The MSMEs only use a small amount of capital as compared to other larger companies. It is mainly because MSMEs are usually located in low-cost industrial areas, in the suburbs, in small towns and villages, and sometimes in their own homes. In terms of employment, most employed or hire workers are either semi-skilled or unskilled workers with less formal education and skills training. MSMEs are a labor-oriented sector where the demands for labor directly reduce unemployment, create employment opportunities for unskilled and semi-skilled workers to earn income, and reduce the income gap among the community.

\section{Entrepreneurship Competencies for Sustainable Performance of MSMEs}

The term entrepreneurship competency refers to the key characteristics that should be possessed by successful entrepreneurs to perform entrepreneurial functions effectively. The competent entrepreneur is expected to combine creativity, innovation, problem-solving, including resources, and financial and technological knowledge to the maximum level. These competencies enable entrepreneurs to adapt to the current situation and changes. A competent entrepreneur will be more capable and more efficient as compared to other entrepreneurs who have the same knowledge and qualifications. Among attributes of entrepreneurial competency are marketing capability, knowledge sharing, financial resources, technology usage, drive change and engagement, and individual competency. McClelland (1987) has listed thirteen characteristics of entrepreneurial competency based on the successful entrepreneurs in Malawi, India, and Ecuador. These characteristics are initiative, seeks and act on opportunities, persistence, information seeking, concern for the high quality of work, commitment to work contract, efficiency orientation, systematic planning, problem-solving, self-confidence, assertiveness, persuasion, and use of influence strategies.

The Covid-19 pandemic crisis has resulted in many countries having travel restrictions, social spacing, and public event postponements. These have caused depression, anxiety, and stress to human behavior and psychology (Abdulghani, Sattar, Ahmad, \& Akram, 2020). The impacts also can be seen in the economic activities due to the closure of retail premises and disruption of product delivery chains (Karabag, 2020). Some entrepreneurs and business owners are starting to take alternative approaches to operate their businesses to ensure income sustainability. Among them, shifting to online sales through social media and mobile applications, such as Facebook and Whatsapp, running a private runner, as well as saving operating costs through downsizing the business (Kusmaharani \& Halim, 2020; Noor Fadhiha, Zuha Rosufila, \& Muhammad Abi Sofian, 2017). With the vast majority of users now active on social media, entrepreneurs need to start taking advantage and focus business models and marketing efforts on social media channels to drive more customer engagement. Gregurec, Tomicic Furjan, and Tomicic-Pupek (2021) suggest that the MSMEs' entrepreneurs need to adjust their business models to adapt to the current economic situation. 
The use of technology in MSMEs is complex as it evolves. These complex changes make it difficult for small-scale entrepreneurs, especially those with rural backgrounds, and less exposed to the more sophisticated and modern technologies to learn it within a short time. Technology speaking, the level of technology used is very low. In other words, they have no skills in handling the technology as they were so used in applying traditional methods rather than through the use of modern technology (Idris \& Rahmah, 2009; Rahmah \& Nor Aini, 2006). A study conducted by Camilleri $(2018 ; 2019 ; 2020)$ revealed that there is a positive and significant relationship between the perceived usefulness of digital media and the pace of technological innovation. The young owner-managers from MSMEs were found more likely to use digital media to improve their stakeholder engagement. Urban and modern entrepreneurs are very dependent, highly skilled, and motivated to use the social media platform in their business dealings (Faradillah, Samsudin \& Nur Ajeerah, 2017). They interact and connect with the customers, build a long-term relationship with them and allow suggestions or opinions from them to improve their products and services.

Rapid technological change today has been influenced the development of the industrial revolution in various sectors around the world. IR4.0 that has affected globally will give fierce market competition in the event of a perpetrator industry in Malaysia is not ready to face it. This IR4.0 revolution has given a big challenge to MSMEs in the face of automation technology as well as human capital development. The adoption of technology and social media is becoming one of the most important aspects of digital marketing which can lead to the sustainable development of MSMEs (Ardjouman, 2015). The introduction of IR4.0 gives an advantage to the entrepreneurs in three things; increasing public awareness on the importance of science and technology-based products, the use of the Internet of Things (IoT), and implementing economicbased innovation (frugal innovation). Products with elements of innovation and technology, which will be more easily accepted by consumers. Due to the Covid-19 pandemic and the MCO implementation, the majority of the customers are now starting to be active in the online and digital world, calling on merchants to dabble in the digital world as well.

Various motivational factors have been identified to be key factors that influence the MSMEs' entrepreneurs to integrate between entrepreneurial knowledge and digital entrepreneurial intention (Ahmad, Saeid \& Mahsa, 2017; Ngoasong, 2015) which are family and academic background, attitude, and skills. Warschauer (2003) on the other hand has introduced some of the key resources needed by the digital entrepreneurs; (1) physical resources - access to computers, (2) digital resources - understand the Internet content, (3) human resources - digital knowledge, and (4) social resources - local communities and institutions which are Internetdependent. However, a study was done by Rofikoh, Permata, and Lin (2018) revealed that there were several issues faced by MSMEs' entrepreneurs with regards to technology acceptance and adoption. The issue of lack of experience and sufficient training of staff, low commitment to technology implementation, low readiness of managers and staff, and high-cost maintenance could hinder the MSMEs to move forwards in marketing their products and services.

Omiunu (2019) in his study disclosed a positive relationship between e-literacy or digital knowledge with the adoption of technology towards the high performance of women-owned MSMEs. MSMEs that took advantage of using technology have to select the right marketing content to enhance strong customer relationships, which leads to their behavior generating sustainable performance for enterprises (Wibowo, Chen, Wiangin, Ma \& Ruangkanjanases, 2021). Nevertheless, are rural MSMEs' entrepreneurs willing to change their minds to shift to automation and innovation technologies in line with industrial revolution 4.0 (IR4.0)? For rural 
MSMEs entrepreneurs, existing infrastructure support may have some constraints that limit business operations during MCO. To ensure business continuity and sustainability, distribution chain support by the government should be taken into consideration. To the best of the authors' knowledge, there were very few studies conducted to discuss the business strategies for the sustainability of the business among rural MSMEs entrepreneurs. Although previous studies are suggesting that firms need to formulate crisis management strategies, (Koonin, 2020; CPA Australia, 2020), such strategies are found to be more relevant for large and developed business firms rather than rural MSMEs. Voluminous studies focused on large-scale businesses, particularly in developing areas (Pine \& McKercher, 2004; Cole \& Watkins, 2015; Noor Fzlinda, Khairul Hanim, \& Juliana, 2020).

Additionally, there is one significant factor that could obstruct the development of MSMEs which is the financial assistance that was discussed by previous researchers (Sheikh \& Md. Mosharraf, 2019; Sibanda, Hove Sibanda, \& Shava, 2018; Isa, Jaganathan, Ahmdon \& Ibrahim, 2018; Chamani, Kulathunga \& Marawansha, 2017; Chowdhury \& Alam, 2017; Dvorsky, Schonfeld, Kotaskova \& Petrakova, 2018; Yusrinadini, Azizi \& Shuhymee, 2016; Hoque, Sultana \& Thalil, 2016). Financial assistance is the most important aspect for the MSMEs' entrepreneurs to market their products and services more widely. MSMEs' access to finance is somehow affected by firm characteristics, policies, and procedures. The size and age of the firm, education, and skills of the owners are some of the biggest challenges of the MSMEs' entrepreneurs to secure loans from financial institutions. Many of the MSMEs' entrepreneurs operate their businesses in rural areas and are often described as less educated entrepreneurs. As a result, they face some financing constraints, particularly concerning the banks' documentation. Among the reasons for the refusal of MSMEs, financing applications were due to insufficient documents, poor credit history, and unsuccessful business plans. Besides, unfavorable credit terms such as high interest rates and lack of collateral security have impacts on credit rationing.

SME Corporation Malaysia which is the central coordinating agency (CCA) under the Ministry of Entrepreneur Development Malaysia (MED) has been set up in 2009 to coordinate the implementation of development programs for MSMEs across all related Ministries and agencies (SME Corporation Malaysia, 2020). The establishment of the MED is to streamline the roles of over 60 Entrepreneur Development Organisations (EDO). For MSME development, the Ministry of Entrepreneur Development (MED) had launched the Entrepreneurship One-Stop Centre (PSK) also known as PSK@SME Hub in October 2018. Among services provided are business advisory hub, SME Hub Links, Pockett talk, Info Centre, SME Product Gallery, and Virtual SME Hub. The hub which can be accessed online and offline provides knowledge and assistance to aid the development of MSMEs. Moreover, these services are in rural areas, which is closer to the rural entrepreneurs. Apart from that, the government has allocated various types of funds and grants to aid MSMEs especially in rural areas, so they can transform their business from traditional entrepreneurial business to digital entrepreneurship. Recently, the government of Malaysia has allocated RM300 million with the purpose to speed up the adoption rate of digital solutions among rural MSMEs through the Economic Stimulus Package (Pakej Rangsangan Ekonomi 2020, 2020). The allocation is channeled to the Malaysia Digital Economy Corp (MDEC). MDEC will be utilizing the fund to further empower the Perkhidmatan e-Dagang Setempat (PeDAS) transformation program that will be focusing on modernizing and digitizing rural internet centers by turning those internet centers into e-commerce hubs so that MSMEs can explore and expand their market opportunities through e-commerce platforms. MSMEs are 
encouraged to utilize these rural internet centers to gain the right digital, entrepreneurial, and ecommerce skills (Adlina, 2020).

A study has been conducted to find out the success factors of women entrepreneurs in Kelantan, one of the states in Malaysia. The findings suggested that environmental and family dimensions, as well as personal attributes, play a big role in the success rate of women entrepreneurs in Kelantan (Kartini, Haslina, Zuraida, \& Norudin, 2015). The involvement of rural women in MSMEs could contribute to the advancement of the national economy. The government has made the MSMEs' development one of the national agendas and a vital resource towards transforming Malaysia's economy into a high-income model. It is undeniable that MSMEs have contributed substantially to the advancement of the national economy, and the call to intensity the involvement of rural MSMEs' entrepreneurs is not only important to the economy, but it is also a path to raising their quality of life. Abdul Jumaat (2012) in his study showed that interest, life impulse, having necessary skills and environmental influence has a significant relationship with women's involvement in MSMEs in Pahang. A similar study also revealed that individual entrepreneur success will work hard to achieve the specific goal, always thinking about the improvement in doing the job, and high confidence level in believing that they can control their life was the need for achievement and entrepreneurial success among women entrepreneurs in Malaysia (Nurwahida \& Abdul Manaf, 2011).

The presence of MSMEs in the rural area of Malaysia is important to boost the economy and income of the rural population. MSMEs currently provide 5.7 million jobs to $70 \%$ of Malaysia's workforce. A total of $98.5 \%$ of all business establishments in Malaysia are MSMEs, and in 2018, MSMEs contributed RM521.7 billion to the nation's gross domestic product (GDP). MSMEs are defined as firms with sales turnover not exceeding RM50 million (or employment not exceeding 200 workers) for manufacturing industries. For the services and other sectors, the threshold was also raised, as firms with sales turnover not exceeding RM20 million or employment not exceeding 75 workers (SME Corporation Malaysia, 2020). All MSMEs must be entities registered with Suruhanjaya Syarikat Malaysia (SSM) or other equivalent bodies. The MSMEs comprise of the individual entrepreneur and group entrepreneurs who have skills and expertise in a particular field and carry on a regular business by selling their products and services.

\section{Accounting and Entrepreneurs}

Although the MSMEs' entrepreneurs can manage their business efficiently, still, there are less knowledgeable about managing accounting and recording transactions of their daily business activities. According to Davis, Dunn, and Boswell (2009), it was found that small businesses do not realize the benefits and advantages of recording and managing their financial statements and prefer not to record their daily transactions. Among the benefits of recording daily transactions and operations are that it will enable them to make better management and financial-related decisions, assist in preparing annual tax payments, and prepare the next planning for the business. Basic knowledge of bookkeeping is essential for small business owners and entrepreneurs to sustain their businesses. From the preparation of the financial statement, the entrepreneur can find out all the financial profits and losses in a business. Some entrepreneurs do not know whether their business is profitable or profitable if they choose not to record their daily transactions and only can estimate the profit or loss of the business. Furthermore, according to Brecht and Martin (1996), Appiah (2014), and Noor Azizi, Shamsul Nahar, and Mahamad 
(2003) entrepreneurs can make use of the non-accounting information from the financial statement in supporting financial information to make better decisions.

Results from Ahmad Zukni (2000) found that some MSMEs' entrepreneurs do record their daily transactions manually. Manual accounting is a paper-based accounting system, in which journals and registers of books, vouchers, and books of account are used to store, classify and analyze the financial transactions of an organization to maintain records of business transactions due to its lower cost. In a country that is moving towards an era of globalization and technology, MSMEs need to make changes to face significant competition in the future. These changes involve the use of good technology in their businesses. Duschinsky and Dunn (1988) revealed that $80 \%$ of the 800 successful MSME entrepreneurs in British are those who use computerized accounting systems. The findings were supported by Noor Azizi, et al (2003), where the use of a computerized accounting system determines the sustainability of the business among MSMEs. The implementation of a computerized accounting system by combining physical and digital documents will save time and money for the company (Nuckles, 2014).

Haleem (2016) in his study describes six factors that hinder to use of computerized accounting systems in government institutions. Those factors are cost, management support, human resources, user views, infrastructure, and internal control systems. Nakyobe, Nambi, Aguti, and Ssewankambo (2016) found that lacking effective staff training on the computerized accounting system can affect the implementation of the system in an organization. According to Amanamah, Morrison, and Aseidu (2016), and Nyang'au, Okibo, and Nyanga'u, (2015), the level of staff education is a factor that will influence the effectiveness of the implementation of accounting systems among MSMEs. Ifinedo (2011) highlights that technological information knowledge is seen as one of the internal factors that have an impact on the success of the implementation of computerized accounting information systems. Other than that, full supports from the top management are important for the MSMEs to use the system effectively (Mohd Fazli, Hoshino, and Md Nor Hayati, 2012). This is because the top management has a significant influence to determine and motivate the employees to use the system.

Today, with the advent of the Covid-19 pandemic that has greatly affected businesses, accounting data is becoming increasingly important to enable entrepreneurs to see the ability of their businesses to continue operations. Knowing the financial health of the business helps the entrepreneur in deciding what should be done through the crisis.

\section{METHODOLOGY}

This is the review study that has examined the determinants of digital accounting entrepreneurship competencies towards the sustainable performance of MSMEs from the flow of existing literature. In this study, the available online empirical recourses by the name of digital accounting entrepreneurship and sustainable performance of the rural MSMEs in different online database sources such as Google Scholars, Springer Link, Wiley, Science Direct, JSTOR, Emerald full text, Scopus, and EBSCO HOST were used for the review. From this search, several journal articles, conference papers, and other types of work have been analyzed to determine which articles need to be included in the review of this paper. After reading thoroughly most relevant articles collected were found best fit within objectives of the present issues about digital accounting entrepreneurship competencies. The review has been examined based on objectives, methods, and findings accordingly to all collected empirical studies. 


\section{DISCUSSION AND CONCLUSION}

The review findings hitherto show that digital accounting entrepreneurship has a significant role in ensuring the sustainable performance of the rural MSMEs, especially for entrepreneurial competency, marketing capability, knowledge sharing, financial resources, technology usage, drive change and engagement, and individual competency is considered the most influencing factors toward sustainable performance among the rural MSMEs in the world. MSMEs entrepreneurs need to think of strategies to plan and control their cash flow to reduce the impact of the pandemic crisis on their business. In Malaysia, various government agencies such as Unit Peneraju Agenda Bumiputera, SME Corporation Malaysia, Tabung Ekonomi Kumpulan Usahawan Niaga, (TEKUN), Nasional, Bank Pertanian, Rural Entrepreneurship Development Division, Jabatan Kemajuan Masyarakat (KEMAS), Department of Youth and Sports, Cradle Fund Sdn Bhd, and other agencies had collaborated with the Ministry to provide financing and coaching program for the aspiring and existing entrepreneurs.

The objectives of the program are to assist MSMEs' entrepreneurs who want to expand their business, create job opportunities and increase the income of the rural population, encourage youth to choose entrepreneurship as a career of choice, finance new entrepreneurs, and establish sustainability in skills development. The entrepreneurs are urged to be more proactive in developing their business and aiming to market their products and services up to the international level. Recently, Prime Minister Tan Sri Muhyiddin Yassin announced to launch of the 'MyDigital - Malaysia's Digital Economic Framework' which is expected to transform the county into a digital economic platform by 2030. The digital economy is expected to contribute $22.6 \%$ to the country's GDP. At the same time, the plan also aims to open 500,000 job opportunities in the digital economy. It includes ideas and plans to improve digital literacy, create high-income jobs, make banking and finance business easier and more organized, provide virtual educational access to our children and bring medical facilities to remote towns. The initiative will complement the country's national development policies such as the Twelfth Malaysia Plan and Shared Prosperity Vision 2030 which emphasizes equitability of outcome through initiative considering the constraints on the achievements of groups or individuals and includes the Malaysia Digital Economy Blueprint.

Thus, the National Policy on Industry 4.0 policy is developed to create a comprehensive ecosystem to support the adoption of IR4.0 and to coordinate the existing resources such as talent and labor, financing, infrastructure, and others as access to smart technologies. The adoption of IR4.0 influences various industries, especially MSME, in enhancing efficiency and productivity level. The Department of Youth and Sports has provided a platform for entrepreneurs to acquire online marketing techniques, to explore online business through practical exposure, to discover online business techniques, and to provide entrepreneurial exposure and education to the MSMEs' entrepreneurs who were interested in becoming a digital entrepreneur. As the global economy continues to grow with the advancement of internet communication technology, many entrepreneurs are taking the opportunity to become digital entrepreneurs by exploring online businesses to help their businesses grow using the digital platform. This digital platform can inspire new creativity with new technologies, markets, and opportunities.

In a conclusion, this study will expose new perspectives on the digital accounting entrepreneurship competency model to the rural community and provides the latest information to the government and stakeholders to create the best strategies for MSMEs' entrepreneurs' business. The impact of technology on the business is inevitable, and for the MSMEs, it is crucial to accept the emerging market conditions and dynamic business environment or invest in 
the digitization of business and the integration of new technologies into their business models. Besides, it shows how digitalization is transforming entrepreneurship and the new venture creation process thanks to digital technological innovation and new venture creation taking place in the digital industry. The digital economy is expected to play an important role in encouraging inclusion and alleviating poverty by reducing information asymmetries for poor or rural workers, thus fostering entry into the productive labor force. Hence, a study of business sustainability strategies during the Covid-19 crisis is necessary. This finding, therefore, warrants a more indepth analysis to develop a digital accounting entrepreneurship competency model.

\section{REFERENCES}

Abdulghani, H. M., Sattar, K., Ahmad, T., and Akram, A. (2020). Association of COVID-19 Pandemic with undergraduate Medical Students' Perceived Stress and Coping. Psychological Research Behaviour Management, 13, 871-881.

Abdul Jumaat, M. (2012). Factors That Encourage Women Involvement in SMEs in Pahang, Malaysia. The Journal of Human Resource and Adult Learning, 8 (2).

Adlina AR (2020), https://www.google.com/amp/s/techwireasia.com/amp/2020/03/malaysiagives-a-boost-to-rural-smes-with-e-commerce-hubs/, (accessed on 6/3/2020)

Ahmad, Y. F., Saeid, K., and Mahsa, M. (2017). The Role of Entrepreneurial Knowledge as a Competence in Shaping Iranian Students' Career Intentions to Start a New Digital Business. European Journal of Training and Development, 41 1), 83-100.

Ahmad Zukni. J. (2000). Ke Arah Mempertingkatkan Latihan dan Kemahiran Bumiputera dalam Perniagaan Agihan. Kertas Kerja Konvensyen Penyertaan Bumiputera dalam Industri Perdagangan Pengedaran, 19-20 September, Kuala Lumpur.

Amanamah, R., Morrison, A., and Asiedu, K. (2016). Computerized accounting system usage by small and medium scale enterprises in Kumasi metropolis, Ghana. Research Journal of Finance and Accounting, 7 (16), 16-29.

Appiah, K. O. (2014). Computerized Accounting Information Systems: Lessons in State-Owned Enterprise in Developing Economies. Journal of Finance and Management in Public Services, 12 (1).

Ardjouman, D. (2015). Marketing Management Strategies Affecting Performance of Small and Medium Enterprises (SMEs) in Cote d'Ivoire. International Journal of Business and Social Science, 6 (4).

Brecht, H. D., \& Martin, M. P. (1996). Accounting information systems: The challenge of extending their scope to business and information strategy. Accounting Horizons, 10, $16-22$.

Camilleri, M. A. (2018). The SMEs' technology acceptance of digital media for stakeholder engagement. Journal of Small Business and Enterprise Development, 26 (4), 504-521.

Camilleri, M. A. (2019). The SMEs' technology acceptance of digital media for stakeholder engagement. Journal of Small Business and Enterprise Development, 26 (4), 504-521.

Camilleri, M.A. (2020). Strategic dialogic communication through digital media during COVID-19. In Camilleri, M.A. (Ed.). Strategic Corporate Communication in the Digital Age, Emerald, UK.

Chamani, M. H. J., Kulathunga, K. M. M. C. B. and Amarawansha, C. (2017). Financial Accessibility of Women Entrepreneurs. International Journal of Scientific and Research Publications, 7 (11).

Chowdury, M. and Alam, Z. (2017). Affecting Access to Finance of Small and Medium 
Enterprises (SMEs) of Bangladesh. USV Annals of Economics and Public Administration, 2 (26), 55-68.

CPA Australia. (2020). Small Business COVID-19 Recovery Toolkit.

Davis, D., Dunn, P., and Boswell, K. (2009). The Importance of Capturing and Using Financial Information in Small Business. American Journal of Economics and Business Administration, 1 (1), 27-33.

Duschinsky, P., and P. Dunn. 1998. "Competitive advantage from IT". Chaintech News, The Institute of Chartered Accountants, April: 7.

Dwivedi, Y. K., Hughes, D. L., Coombs, C., Constantiou, I., Duan, Y., Edwards, J. S., Gupta, B., et al. (2020). Impact of COVID-19 pandemic on information management research and practice: Transforming education, work, and life. International Journal of Information Management, 7, 102211.

Dvorsky, J., Schonfeld, J., Kotaskova, A., and Petrakova, Z. (2018). Evaluation of important credit risk factors in the SME segment. Journal of International Studies, 11 (3), 204-216.

European Commission (2015). European Commission (EC), Digital Transformation of European Industry and Enterprises; A report of the Strategic Policy Forum on Digital Entrepreneurship, available from http://ec.europa.eu/DocsRoom/documents/9462/attachments/1/translations/en/renditions/ native

Faradillah, I. O., Samsudin A. R., and Ali, S. (2015). Penyertaan digital dan ciri keusahawanan dalam permerkasaan usahawan wanita di Malaysia. Malaysian Journal of Communication, 3 (1), 241-256.

Faradillah I. O., Samsudin, A. R. \& Husna, A. D. (2019). Analisis Pola Penyertaan Digital ICT dan Transformasi Keusahawanan (Analysis of Digital Inclusion Pattern and Entreprenuership Transformation). Jurnal Komunikasi: Malaysian Journal of Communication, 35 (2), 314-330

Faradillah, I. O., Nur Ajeerah, O., and Nor Azlili, H. (2019). Digital Inclusion of ICT And Its Implication Among Entrepreneurs of Small and Medium Enterprises. International Journal of Engineering and Advanced Technology, 8 (5C)

Ghani, F. A. (2020). Impak psikologi akibat wabak Covid-19, Astro Awani, 14 Mac 2020, retrieved from http://www.astroawani.com/berita-malaysia/impak-psikologi-akibatwabak-covid-19-233648

Gregurec, I., Tomičić Furjan, M., Tomičić-Pupek, K. (2021). The Impact of COVID-19 on Sustainable Business Models in SMEs. Sustainability, 1 (13), 1098.

Haleem, A. (2016). The factor affecting computerized accounting system concerning government department in the Ampara District. International Journal of Economic and Business Review, 4 (7), 130-139.

Hoque, M. Z., Sultana, N. and Thalil, T. (2016). Credit rationing's determinants of Small and Medium Enterprises (SMEs) in Chittagong, Bangladesh. Journal of Global Entrepreneurship Research, 6 (1), 1-23.

Idris, J. and Rahmah, I. (2009). Technical progress and labor productivity in small and medium scale industry in Malaysia. European Journal of Economics, Finance, and Administrative Science, 15, 199 - 208.

Ifinedo, P. (2011). Examining the influences of external expertise and in-house computer/ IT knowledge on ERP system success. The Journal of Systems and Software, 84, 20652078. 
Isa, F. M., Jaganathan, M., Ahmdon, M. A. S., and Ibrahim, H. M. (2018). Malaysian Women Entrepreneurs: Some Emerging Issues and Challenges of Entering the Global Market. International Journal of Academic Research in Business and Social Sciences, 8 (12), 1596-1605.

Jones, M.V., Coviello, N.E., (2005). Internationalization: conceptualizing an entrepreneurial process of behavior in time. Journal of International Business Studies, 36 (3), 284-303.

Karabag, S. (2020). An Unprecedented Global Crisis! The Global, Regional, National, Political, Economic and Commercial Impact of the Coronavirus Pandemic. Journal of Applied Economics and Business Research, 10 (1), 1-6

Kartini, M. R., Haslina, C. N., Zuraida, M., and Norudin, M. (2015). Success Factors Among Women Entrepreneurs in Malaysia. International Academic Research Journal of Business and Technology. 1 (2), 28-36.

Kraus, S., Kailer, N., Kallinger, F. L., and Palmer, C. (2019). Digital entrepreneurship: A research agenda on new business models for the twenty-first century. International Journal of Entrepreneurial Behaviour \& Research, 25 (2), 353-375.

Koonin, L. M. (2020). Novel coronavirus disease (COVID-19) outbreak: Now is the time to refresh pandemic plans. Journal of Business Continuity \& Emergency Planning, 13 (4), $1-15$.

Kusmaharani, A. S., \& Halim, R. E. (2020). Social Influence and Online Impulse Buying of Indonesian Indie Cosmetic Products.Jurnal Ilmiah Manajemen, 10 (2), 237-248.

Le Dinh, T., Vu, M. C. \& Ayayi, A. (2018). Towards a living lab for promoting the digital entrepreneurship process. International Journal of Entrepreneurship, 22 (1), 1-17.

McClelland, D.C. (1987), "Characteristics of successful entrepreneurs", The Journal of Creative Behavior, 21 (3), 219-233.

Mohd Fazli, M. S., Hoshino, Y., and Nor Hayati, T. (2012). The Adoption of Computerized Accounting System in Small Medium Enterprises in Melaka, Malaysia (SSRN Scholarly Paper No. ID 2204182). Rochester, NY: Social Science Research Network. Retrieved from https://papers. ssrn.com/abstract=2204182

Mohd Rosli, M. (2000) Industri kecil dan sederhana: landasan pembangunan usahawan / Mohd Rosli Mohamad. Penerbit Universiti Malaya, Kuala Lumpur. ISBN 9831001044

Musbri, M. (2011). E-Dagang \& Undangundang: Perlindungan Pengguna Dalam Transaksi Jualan Barang di Malaysia

Nakyobe, J., E. Nambi, E Aguti, and W Ssewankambo. 2016. Implementation of a Computerized Accounting System at RUFORUM. Working Document Series, 277-86. Cape Town, South Africa.

Nambisan, S. (2017). Digital Entrepreneurship: Toward a Digital Technology Perspective of Entrepreneurship. Entrepreneurship: Theory and Practice, 41 (6), 1029-1055.

Ngoasong, M. Z. (2015). Digital Entrepreneurship in Emerging Economies: The role of ICTs and local context. In: 42nd AIB-UKI Conference, 16-18 Apr 2015, Manchester Metropolitan University, UK.

Noor Azizi, I, Shamsul Nahar, A., and Mahamad, T. (2003). Computer-Based Accounting Systems: The Case of manufacturing-based Small and Medium Enterprises in the Northern Region of Peninsular Malaysia. Jurnal Teknologi, 39 (E), 19-36.

Noor Fadhiha, M., Zuha Rosufila, A. H., and Muhammad Abi Sofian, A. H. (2017). The Social Media and Marketing Strategies: How it Impacts the Small- and Medium-sized Enterprises' Business Performance. Australasian Journal of Business, Social Science and 
Information Technology, 3 (4), 184-190.

Noor Fzlinda, F., Khairul Hanim, P., and Juliana, L. (2020). The Impact of Covid-19 Pandemic Crisis on Micro-Enterprises: Entrepreneurs' Perspective on Business Continuity and Recovery Strategy. The Asian Institute of Research Journal of Economics and Business, 3 (2), 837-844.

Nuckles, B. (2014). How SMS Marketing Can be Your Business' Resolution. Retrieved from https://www.swiftsmsgateway.com/2014/01/07/how-sms-marketing-can-be-yourbusiness-resolution/

Nurwahida, F. and Abdul Manaf, B. (2011). Malay Women Entrepreneurs in the Small and Medium-Sized ICT-Related Business: A Study on Need for Achievement. International Journal of Business and Social Science, 2 (13)

Nyang'au, R.N., Okibo, B.W., and Nyanga'u, A. (2015). Constraints affecting adoption of computerized accounting system in 160 Nyeri County, Kenya. International Journal of Economics, Commerce and Management, 3 (5), 15-36

Omiunu, O. G. (2019). E-literacy-adoption model and performance of women-owned SMEs in Southwestern Nigeria. Journal of Global Entrepreneurship Research, 9 (26)

Pakej Rangsangan $\quad$ Ekonomi $2020 \quad$ (2020), https://www.treasury.gov.my/pdf/pre2020/Booklet_Pakej_Rangsangan_Ekonomi_2020. pdf. (accessed on 1/4/2021)

Park, J. Y., Sung, C. S., and Im, I. (2017). Do Social Media Use Influence Entrepreneurial Opportunity? A Review of its Moderating Role. Sustainability, 9, 1593

Pine, R. and McKercher, B. (2004), "The impact of SARS on Hong Kong's tourism industry", International Journal of Contemporary Hospitality Management, 16 (2), 139-143.

Rahmah, I. and Nor Aini, H. I. (2006). The Impact of Information and Communication Technology Utilisation on Firm Performance: A Case Study of Women Entrepreneurs. Malaysian Management Journal 10 (1 \& 2), 19-32

Rippa, P., and Secundo, G. (2019). Digital academic entrepreneurship: The potential of digital technologies on academic entrepreneurship. Technological Forecasting and Social Change, 146 (C), 900-911

Rofikoh, R., Permata, W. and Lin, M. (2018). Small Medium Enterprises Technology Acceptance Model: A Conceptual Review. International Journal of Business and Society, 19 (4), 689-699

Saleh, A. S. and Ndubisi, N. O. (2006). An evaluation of SME development in Malaysia. International Review of Business Research Papers, 2 (1), 1-14

Shabbir, M. S., Ghazi, M. S. and Mehmood, A. R. (2016). Impact of Social Media Applications on Small Business Entrepreneurs. Arabian Journal of Business and Management Review. 6 (3), 203

Sheikh, M. I., and Mosharraf, M. H. (2019). Women Entrepreneurship in Bangladesh: Influential Factors of Women Participation in the SMEs Area. International Journal of Science and Business, 3 (3), 151-161

Sibanda. K., Hove Sibanda, P., Shava, H. (2018). The impact of SME access to finance and performance on exporting behavior at the firm level: A case of furniture manufacturing SMEs in Zimbabwe. Acta Commercial, 18 (1), 554.

SME Corporation Enterprise (2020), http://www.smecorp.gov.my/index.php/en/about-smecorp-malaysia (accessed 6/3/2020)

Suriatie, M. Y. and Nor Aishah, B. (2017). Pendekatan penggunaan medium epemasaran dalam 
kalangan usahawan wanita. Journal of Global Business and Social Entrepreneurship (GBSE), 1(1), 47-57.

Warschauer, M. (2003). Technology and social inclusion: Rethinking the digital divide. Cambridge: MIT Press

Wibowo, A., Chen, S. C., Wiangin, U., Ma, Y., Ruangkanjanases, A. (2020). "Customer Behavior as an Outcome of Social Media Marketing: The Role of Social Media Marketing Activity and Customer Experience," Sustainability, MDPI, Open Access Journal, 13 (1), 1-18.

Yusrinadini, Z. M. I. and Azizi, A. B. (2016). Determinants Factors of Women Entrepreneurs' Business Performance: A Conceptual Framework. Journal of Global Business and Social Entrepreneurship, 1 (1), 55-67.

\section{Copyrights}

Copyright for this article is retained by the author(s), with first publication rights granted to the journal. This is an open-access article distributed under the terms and conditions of the Creative Commons Attribution license (https://creativecommons.org/licenses/by/4.0) 